\title{
Investigation and Study on the Physical Education students' concept of love
}

\author{
ShuMei Yi, Wusi Yan \\ Pingxiang University, Pingxiang 337055, China
}

\begin{abstract}
It became more and more popular that Physical Education students fall in love, their motivation, attitude towards love and the ability to handle the lovelorn are still relatively simple because of the age, so we must strengthen the education on the concept of love in the first grade and guide them to form the healthy concept of love.
\end{abstract}

Keywords: Physical Education; University students; the concept of love.

\section{Introduction}

In March 2005, the national Ministry of Education promulgated the regulations on the management of students in Colleges and universities, and abolished the regulations that the university students are not allowed to get married, which contributed to the formation of the atmosphere of love. Physical Education students because of the particularity of the professional nature, extrovert, lively active, the body better, the good appearance of temperament characteristics, there will be a advantage in love.At the same time, the rate of broken love also occupy a certain proportion, the result may be more serious than other professional students because of the result of the love. Therefore, how to carry on the correct guidance and intervention to the students' love affairs, and put forward some reasonable suggestions and countermeasures, and help them set up the correct outlook on love and life.

\section{The research objects and methods}

\subsection{The research object}

This paper investigates 116 students in the department of Pingxiang University, including 95 boys and 21 girls.

\subsection{The research methods}

Literature review: a review of the college students' love view and the relevant aspects of the questionnaire.

Questionnaire investigation method: according to the students' love view investigation and design of the two sets of questionnaires, a set of is Knox love tendency scale and another set is about sports professional students to talk about the practice and views of love. A total of 116 questionnaires were issued and 116 questionnaires were returned, including 104 points, 83 boys and 21 girls.

Statistical method: the results of the survey using Excel software for statistical processing.

\section{The research results and analysis}

\subsection{The sports professional college students' love tendency}

Based on theory of Knox and J Paula Koski can the students love inclined is divided into two kinds of romance and reality. Romance is full of excitement, fantasy and longing for love, less attention to some practical problems; reality is the focus on the reality of the characteristics, the relationship is stable and harmonious. At the same time, Knox and a survey of College Students' love tendency questionnaire, a total of 26 questions, with 1 - 5 were expressed strongly agree, agreed moderately, bad decisions, some do not agree, and resolute dont agree etc. five different degree, students can think in the appropriate option on scoring. Finally, the subject of all points are added, the higher the score, the close to reality.

After investigation and statistics of 104 students in the sports department, they were divided into four groups according to different grades and genders. In order to detect whether there is a significant 
difference between the four groups, the paper used the method of single factor analysis of variance (Table 1). The $F=1.403<F$ threshold value (2.696) was obtained. And with increasing grade, regardless of boys, or girls, scores are on the rise, suggesting that the higher the grade, the older, the attitude of love is behaved increasingly realistic, this may and their plans for the future have certain relationship.

Table 1 Single factor analysis of variance

\begin{tabular}{ccccccc}
\hline Differences source & SS & df & MS & F & P-value & F crit \\
\hline Between groups & 195.2029 & 3 & 65.06764 & 1.403967 & 0.246115 & 2.695534261 \\
Within the group & 4634.557 & 100 & 46.34557 & & & \\
Total & 4829.76 & 103 & & & & \\
\hline
\end{tabular}

Table 2 Different grades, gender College Students' Love tables

\begin{tabular}{ccccc}
\hline Group & Number of observations & Sum & Average & Variance \\
\hline Sophomore (M) & 30 & 2188 & 72.93333 & 26.68506 \\
Sophomore (Female) & 7 & 537 & 76.71429 & 53.2381 \\
Freshman (M) & 53 & 3852 & 72.67925 & 61.6836 \\
Freshman (Female) & 14 & 1062 & 75.85714 & 25.67033 \\
\hline
\end{tabular}

\subsection{The sports professional students' love situation}

From the survey results can be seen, sports professional college students did not oppose the love, clearly expressed in favor of the proportion of two grade boys are higher than girls, and the sophomore (38\%) to be higher than the freshman (28\%) 10 percentage points, and take the attitude of the nature to be higher than the Sophomore, the ratio was $54 \%$ and $49 \%$. Most of the students have a talk about love experience, which has been talked about but now not to talk about the proportion of large and even higher than the sophomore, that the current high school students in high school began to fall in love, and with the increase in the proportion of $24 \%$, which shows that college students are not sure about the impact of love.

Table 3 The attitude towards love statistics (the number/percentage)

\begin{tabular}{|c|c|c|c|c|c|c|c|c|}
\hline \multirow{2}{*}{ Question } & \multirow{2}{*}{ Options } & \multicolumn{3}{|c|}{ Freshman } & \multicolumn{3}{|c|}{ Sophomore } & \multirow{2}{*}{$\begin{array}{l}\text { The total } \\
\text { percentage }\end{array}$} \\
\hline & & Man & Female & Average & Man & Female & Average & \\
\hline \multirow{3}{*}{$\begin{array}{l}\text { Attitude } \\
\text { to love }\end{array}$} & $\begin{array}{l}\text { Let nature take } \\
\text { its course }\end{array}$ & $27 / 51 \%$ & $9 / 64 \%$ & $36 / 54 \%$ & $15 / 50 \%$ & $3 / 43 \%$ & $18 / 49 \%$ & $51.9 \%$ \\
\hline & Agree & $16 / 30 \%$ & $3 / 21 \%$ & $19 / 28 \%$ & $12 / 40 \%$ & 2/28.5\% & $14 / 38 \%$ & $30.8 \%$ \\
\hline & It doesn't matter & $10 / 19 \%$ & $2 / 15 \%$ & $12 / 18 \%$ & $3 / 10 \%$ & $2 / 28.5 \%$ & $5 / 13 \%$ & $16.3 \%$ \\
\hline \multirow{3}{*}{$\begin{array}{l}\text { Ever talk } \\
\text { about } \\
\text { love }\end{array}$} & $\begin{array}{l}\text { Is falling in } \\
\text { love }\end{array}$ & $11 / 21 \%$ & $5 / 36 \%$ & $16 / 24 \%$ & $15 / 50 \%$ & $2 / 28.5 \%$ & $17 / 46 \%$ & $31.7 \%$ \\
\hline & $\begin{array}{l}\text { Ever but now } \\
\text { don't have to } \\
\text { fall in love }\end{array}$ & $37 / 70 \%$ & $6 / 43 \%$ & $43 / 64 \%$ & $9 / 30 \%$ & $2 / 28.5 \%$ & $11 / 30 \%$ & $51.9 \%$ \\
\hline & $\begin{array}{l}\text { Have to } \\
\text { consider, but } \\
\text { not to start }\end{array}$ & 0 & $3 / 21 \%$ & $3 / 4 \%$ & $3 / 10 \%$ & $1 / 14 \%$ & $4 / 11 \%$ & $6.7 \%$ \\
\hline \multirow{3}{*}{$\begin{array}{l}\text { If impact } \\
\text { study }\end{array}$} & $\begin{array}{l}\text { Have an impact } \\
\text { on }\end{array}$ & $16 / 30 \%$ & $1 / 7 \%$ & $17 / 25 \%$ & 0 & $1 / 14 \%$ & $1 / 3 \%$ & $17.3 \%$ \\
\hline & No effect & $16 / 30 \%$ & $5 / 36 \%$ & $21 / 31 \%$ & $10 / 33 \%$ & $3 / 43 \%$ & $13 / 35 \%$ & $32.7 \%$ \\
\hline & Not sure & $21 / 40 \%$ & 8/57 \% & $29 / 44 \%$ & $20 / 67 \%$ & $3 / 43 \%$ & $23 / 62 \%$ & $50 \%$ \\
\hline
\end{tabular}




\subsection{The sports professional students' love motivation}

From the college students' understanding of love, the survey found that contemporary college students are influenced by the influence of the side of a friend, the total proportion of $34.6 \%$, in contrast to the school education, books, television network for their understanding of love is only $18.3 \%, 2.9 \%$ and $11.5 \%$.

Love motivation is mainly to promote college students in the psychological formation of the internal power or desire to talk about love, through the survey found that the love motivation of sports professional college students in the top four is actually consistent, just a different sort. Boys are mainly from "out of sincerity, established his family" and "to find a like-minded lover" two aspects to consider, the ratio was $91.6 \%$ and $75.9 \%$, and girls from the "find a like-minded lover" (61.9\%) and "love experience" (52.4\%) considered; in 11 motivation option, no boy out "catch the trend" and "show off" and love, girls in addition to the two, there is no people in order to get physical and physiological satisfaction "and love. That sports professional students' motivation of love is very simple, in the sports professional students' management and ideological education process can not generalize, to be appropriate guidance.

\subsection{The standard and influence factors of mate choice for sports majors}

In the selection of lovers of the standard, sports professional students are more focused on moral character and character, male, female character and personality of the proportion were $90.4 \%, 81.9 \%$ and $81 \%, 85.7 \%$, can see the boys more fancy is moral character, girls tend to character, in addition, they have a high degree of health of the lovers, but the family situation and educational background, etc.. In comparison, appearance (59.5\%) is a very important criterion for choosing a lover of sophomore.

\subsection{The sports professional students' love view education}

Through the survey found: sports professional students in love, $64.4 \%$ of the students think that will "lose the opportunity to get along with other friends"; $61.5 \%$ of the students believe that will "increase spending"; $51.9 \%$ of students think "will put too much energy". Only $20.2 \%$ and 17.3\% of the students think that it will "waste a lot of time to read" and "influence learning". In the view of the phenomenon of cohabitation of college students, there are as high as $46.2 \%$ of the students take the attitude that the "high efficiency of the prohibition of cohabitation of students is necessary" only 22.1\%, "agree" and "firmly opposed" are also 24\% and 7.7\%. Therefore, this also led to only 33.7\% of the students believe that the university is necessary to carry out the education of love, think it is necessary to only $26.9 \%$, there are $30.8 \%$ students is indifferent attitude.

\subsection{The sports professional students to treat the attitude of love}

In the face of romance to break up, most sports professional students (81.7\%) would "offer" and "fate", and only a handful of students will look "at a loss" and "tangle with each other". No students think that after be lovelorn "life becomes meaningless". Most of them can be "calmly accept" (66.3\%) and "from the shadows out to do other things" (51\%). On the one hand, these phenomena show that the students of physical education are more open and bright, and their psychological endurance is stronger. On the other hand also reflects that they have not understood the true meaning of love, the value of love is not high.

\section{The conclusions and recommendations}

\subsection{The conclusions}

The girls of Physical Education students in love is more realistic than the boys, and with the increase of grade performance more realistic.

Physical Education students to talk about the phenomenon of love is more common, some students from high school have a love experience, and most students can not be well deal with the relationship between love and learning.

Contemporary Physical Education students' love motivation is simple, not to show off or compare the like, but the friends around their psychological role in promoting the role of a subtle. 
Physical Education students cannot understand the true meaning of love, love behavior is still in the blind, which also led to the students can not be a good understanding of the importance of education and the rights to look at the phenomenon of cohabitation, the majority of students do not take the attitude.

How to deal with a breakup, the Physical Education students is more generous, can take the initiative to request, and can calmly accept the fact.

\subsection{The suggestions}

Needs to start from the freshman to start a love concept education, provide the students with the guidance in this field, and lay a certain foundation for the students to establish a correct outlook on love.

The school, the Department of leadership, the teacher should pay attention to the students' love affairs, strengthen the management of the students in love, and correct guidance to help them deal with the relationship between love and education.

Through various forms of activities, on the one hand to make students establish the correct values of love, on the other hand, the students love, love and other psychological aspects of the psychological aspects of debugging, and guide students to correctly deal with setbacks in love.

Students themselves should strengthen the study of personal moral cultivation, to resist some of the love ideas, to cherish the time in college, and strive to improve their professional skills.

\section{References}

[1] Fengying Li. The ecological analysis of the ethical problems of the college students in sports [J]. Journal of Mudanjiang University, 2012 (7)

[2] Youru Yu. On the part of Chinese college students majoring in Physical Education in love psychological status investigation and countermeasures [J]. Jinggangshan University Journal, 2007 (2)

[3] Yunping Han Erikson, the psychological development of college students in the school of love [J]. Journal of Kunming College of Metallurgy, 2004 (1)

[4] Xianjun Chen. On the college students' love motivation and the advantages and disadvantages of [J]. Journal of West Anhui University, 2004 (3)

[5] Jianchang Chen, Fu. The investigation and analysis of psychological health of college students of physical education major. [J]. Journal of Shaoguan University, 2008 (6) 